ACTA AGROBOTANICA

Vol. 62 (2): 125-135

2009

\title{
THE OCCURRENCE AND BIOTIC ACTIVITY OF Phomopsis diachenii SACC.
}

\author{
Zofia Machowicz-Stefaniak
}

\begin{abstract}
Department of Plant Pathology and Mycology, University of Life Sciences in Lublin, Leszczyńskiego 7, 20-069 Lublin, Poland e-mail: zofia.machowicz@up.lublin.pl
\end{abstract}

Received: 4.06.2009

Abstract

Phomopsis diachenii was isolated from caraway cultivars Konczewicki, firstly in 2006 and next in 2007. Single cultures were obtained from the roots and the stem base of eight six-week-old seedlings and from the stems of two plants with symptoms of necrosis, in the second year of planting. This fungus was isolated from the plant parts superficially disinfected on malt agar medium with an addition $0.01 \%$ of streptomycin. The identification of the species was made on PDA medium. The biotic interactions between $P$. diachenii and $S$. carvi and other species of phyllosphere fungi of caraway were studied. Interactions among the fungi, i.e. between $P$. diachenii and one of the fungi representing the studied community, were examined using the biotic series method. The biotic effects of the fungi in dual cultures were evaluated after 10 and 20 days of common growth and were expressed as the individual biotic effect (IBE). It was shown that $P$. diachenii is a weak competitor because its growth was limited by numerous species of phyllosphere fungi. The obtained results indicated the dominance of biotic activity of $P$. diachenii over that of $S$. carvi. It is possible that $P$. diachenii has a greater ability to survive in the phyllosphere fungal community than $S$. carvi, causing septoriosis of caraway.

Key words: Phomopsis diachenii, occurrence, biotic activity, caraway

\section{INTRODUCTION}

Fungi from the genus Phomopsis are known as commonly occurring pathogens of plants from various botanical groups. Many species were identified both on spices and herbs (U c ker, 1988; F arr et al. 1995). This species includes Phomopsis sclareae occurring on sage, $P$. subordinaria was found on ribword plantain and $P$. lavandulae attacked lavender plants in various European countries (U e c k e r, 1988; L a i n e, 2003; Zimowska, 2008). Phomopsis foeniculi was observed on fennel in Italy, France and Germany (M u g nai and Anzidei, 1994; Kusterer et al. 2002) and $P$. diachenii (S a c c a r d o, 1915; S u t t o n , 1980;
F a r r et al. 1995), belonging to the species, occurred on Apiaceae plants. According to the papers of the above mentioned authors, parsnip was recognized as the first host of $P$. diachenii, and it was not supposed that this species could infect other Apiaceae plants for a long time. In $1988 P$. diachenii was first found on caraway (Carum carvi L.) in Germany ( $\mathrm{Gab}$ le r and Ehrig, 2000). The fungus was recognized as a dangerous pathogen of caraway umbels in various phases of their development. $P$. diachenii caused their browning, decay and total necrosis of the other parts of this plant, except the roots and the base of stems (Gabler and Ehrig, 2000). These authors confirmed high harmfulness of this fungus to caraway in pathogenicity tests (G a ble r and Ehrig, 2000). In recent years $P$. diachenii has been found on caraway in the Czech Republic, Bulgaria and Lithuania (G a b l e r and Machowicz-S tefaniak, 2004; R odeva and Gabler , 2004). During the studies on caraway diseases in Poland in 1998, the discussed pathogen was not recorded for a long time, although on the aboveground parts of plants various species of fungi were recorded and Septoria carvi was recognized as a more dangerous pathogen for umbels, schizocarps, stems and leaves (M a chow ic z-S te faniak and Zalewska, 2008; Zalewska, 2008). Despite the fact that these two mentioned species have similar thermal requirements, i.e. the optimal temperature for growth and development of $P$. diachenii is $25^{\circ}-28^{\circ} \mathrm{C}$ (Gabler and Ehrig, 2000) and $20^{\circ}-25^{\circ} \mathrm{C}$ for S. carvi (Zalewska not published), and very hot vegetative periods occurred, $S$. carvi showed to be the main pathogen of caraway in Poland. The fact that in recent years several isolates of $P$. diachenii have been obtained from caraway suggests that the growth of this fungus could be limited by other fungi colonizing host plant tissues, and this fact was indicated earlier with respect to $S$. carvi (M a c how i c z - S te f a n i a k et al. 2008). It seems most probable that, within the consider- 
able biodiversity of fungi colonizing the aboveground parts of caraway plants, there occurred antagonistic microorganisms, i.e. Trichoderma spp., Gliocladium spp., Epicoccum sp., and fast growing species from the genera Alternaria, Fusarium, Botrytis, Colletotrichum and Rhizoctonia (F a r r et al. 1995; M a c how i c zStefaniak and Zalewska, 2004; 2008; Machowicz-Stefaniak et al. 2003).

The above mentioned data inspired us to study macroscopic and microscopic features of our native isolates of the pathogen and to study the biotic interactions between $P$. diachenii and $S$. carvi and other species of phyllosphere fungi of caraway.

\section{MATERIALS AND METHODS}

The material used for the study consisted of native isolates $\mathrm{K} 255, \mathrm{~K} 257$ and $\mathrm{K} 561$ of $P$. diachenii obtained as a result of a study on caraway disease in the years 2005-2007 as well as three isolates 72, 6 and Ondr. of this fungus obtained from BA f. Züchtungsforschung an Kulturpflanzen Inst. f. Resistenzforschung und Pathogendiagnostik in Aschersleben.

The native isolates of the fungus were obtained during the isolation of the fungi from various parts of caraway cultivated in the Lublin region. The fungi were isolated from the plant parts superficially disinfected in a $10 \%$ solution of sodium hypochlorite for 1.5 minute on malt agar medium with $0.01 \%$ addition of streptomycin (G abler and Ehrig, 2000; Machowicz-Stefaniak and Zalewska, 2004; 2008). One spore cultures of $P$. diachenii were grown on PDA medium, which is recognized as adequate for growing a lot of microscopic fungi species (Sutton, 1980). The fungus cultures were studied for 20 days of growing on culture medium at a temperature $25^{\circ} \mathrm{C}$ in dark conditions. The character of the cultures, the shape, size and dimension of pycnidia and conidia of $P$. diachenii were determined on the basis of 180 pycnidia (60 per three isolates) and 300 conidia $\alpha$ and 300 conidia $\beta$ (100 per three isolates). To identify the species, light and scanning electron microscopy (SEM) was used. The character and microscopic features of the native isolates were compared with the foreign cultures of $P$. diachenii. Based on the description of Sutton (1980) and G abler and Ehrig (2000), the identification of the studied isolates was made.

To study the biotic interactions of caraway phyllosphere fungi (Machowicz-Stefaniak et al. 2008), two isolates of $P$. diachenii, i.e. 72 and $\mathrm{K} 561$, as well as isolates of the species mentioned in Tab. 2 were taken. Because of the lack of information about the biotic relationships between $P$. diachenii and other species, the maximum number of fungal species was taken for this study, irrespective of the frequency of their isolations from caraway plants (Machowicz-Stefaniak and Zalewska, 2004; Machowicz-Stefaniak et al. 2008). The species Gliocladium catenulatum, $G$. roseum and $T$. viride taken into consideration originated from other cultivated plant species, because they were not isolated from caraway in the years of the study (MachowiczStefaniak, 1998; Machowicz-Stefaniak and $\mathrm{Zalewska,2000).} \mathrm{The} \mathrm{interactions} \mathrm{among} \mathrm{the}$ fungi, i.e. between $P$. diachenii and one of the fungi representing the studied community, were studied using the biotic series method, according to $\mathrm{Man} \mathrm{ka}$ (1974), Mańka and Mańka (1992) and M ańka (1995), on PDA (Difco) medium, solidified in Petri dishes. Dishes with the mycelium of single fungal species constituted the control. For each experimental combination, i.e. $P$. diachenii and one of the fungus species representing the community and the control, four replications (dishes) were made. The biotic effects of the fungi in dual cultures were evaluated after 10 and 20 days of common growth, using an eight-degree scale.

The evaluation of biotic effects of the fungi was the arithmetic sum of three points: the first one - the surrounding of the pathogen colony by other fungi species, the second one - the occurrence of an inhibition zone between the colonies, and the third - the reduction of the size of one of the fungus colony ( $\mathrm{M} \mathrm{a} \mathrm{n} \mathrm{k} \mathrm{a}$, 1995). If the colony of $P$. diachenii was overgrown by other fungi species, the appearance of the mycelium and conidia of the studied fungus was evaluated. The biotic effect of the fungi community representing the caraway phyllosphere and $P$. diachenii was expressed as an individual biotic effect (IBE) (M a ń k a , 1974). The positive value of IBE indicates the suppressive effect on pathogen growth, the negative value of IBE indicates the absence of the suppressive effect on pathogen growth, while the effect may be "0" as well, which indicates a neutral influence (M a ń k a, 1974; Mańka, 1995).

\section{RESULTS}

The native isolates of $P$. diachenii were isolated from caraway plants cv. Konczewicki. These cultures were obtained from the roots and the base of stems of eight six-week-old seedlings in 2006 and from the stems of two plants in 2007 in the second year of planting. The studied pathogen was not isolated in 2005 . The fungus was obtained from caraway organs with lesions of nonspecific shape and size. Moreover, P. diachenii has not been isolated from leaves, umbels and schizocarps of caraway so far.

The diameter of twelve-day-old colonies on PDA medium ranged from 65.0 to $80.0 \mathrm{~mm}$ and after 20 


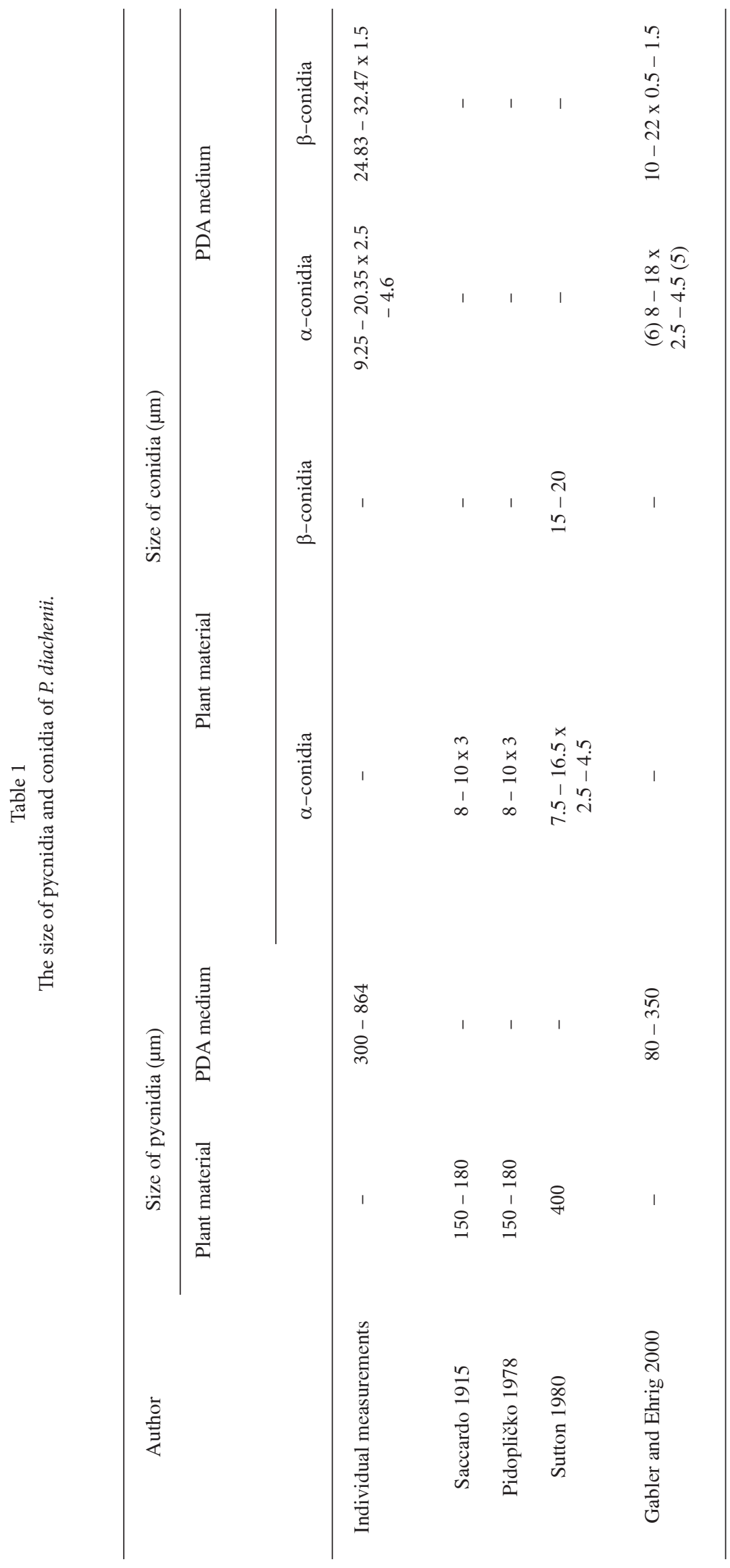


Table 2

The biotic effect of fungi isolated from caraway (Carum carvi L.) on Phomopsis diachenii.

\begin{tabular}{|c|c|c|c|c|}
\hline \multirow{4}{*}{ Isolates of fungi } & \multicolumn{4}{|c|}{ Individual biotic effect - IBE } \\
\hline & \multicolumn{2}{|c|}{ after 10 days } & \multicolumn{2}{|c|}{ after 20 days } \\
\hline & \multicolumn{2}{|c|}{ isolates of $P$. diachenii } & \multicolumn{2}{|c|}{ isolates of $P$. diachenii } \\
\hline & 72 & K561 & 72 & K561 \\
\hline Alternaria alternata (Fr.) Keissler (K 461) & 0 & 0 & +5 & +4 \\
\hline Alternaria radicina Meier, Drechsler et Eddy (K 1723) & 0 & 0 & +3 & +4 \\
\hline Botrytis cinerea Pers. (K 1777) & +8 & +8 & +8 & +8 \\
\hline Cladosporium cladosporioides (Fres.) de Vries (K 518) & 0 & 0 & +3 & +2 \\
\hline Colletotrichum dematitum (Pers. ex Fr.) Grove (K 425) & -6 & -6 & -7 & -7 \\
\hline Colletotrichum gloeosporioides (Penz.) Sacc. (K 1818) & +3 & +3 & +6 & +6 \\
\hline Epicoccum purpurascens Ehrenberg (K 1696) & +3 & +3 & +7 & +7 \\
\hline Fusarium avenaceum (Fr.) Sacc. (K 456) & +2 & +2 & +6 & +6 \\
\hline Fusarium culmorum (W.G.Smith) Sacc. (K 284) & +2 & +3 & +5 & +5 \\
\hline Fusarium equiseti (Corda) Sacc. (K 304) & +3 & +3 & +6 & +6 \\
\hline Fusarium oxysporum Schlecht (K 271) & +2 & +2 & +4 & +5 \\
\hline Fusarium sporotrichioides Sherb (K 465) & +4 & +4 & +5 & +6 \\
\hline Phoma exigua Desm. var. exigua (K 1503) & +1 & 0 & +6 & +4 \\
\hline Rhizoctonia solani Kühn (K 1561) & +6 & +6 & +8 & +8 \\
\hline Septoria carvi Syd. (K 1833) & -2 & -2 & -4 & -4 \\
\hline$($ K 860) & -3 & -3 & -6 & -6 \\
\hline Gliocladium catenulatum Gilman et Abbott (L 4940) & +2 & +2 & +8 & +8 \\
\hline Gliocladium roseum Bainier (L 830) & +2 & +2 & +8 & +8 \\
\hline Trichoderma harzianum Rifai (K 428) & +8 & +8 & +8 & +8 \\
\hline Trichoderma koningii Oud. (K 437) & +8 & +8 & +8 & +8 \\
\hline Trichoderma viride Pers. ex Gray (W 1222) & +8 & +8 & +8 & +8 \\
\hline
\end{tabular}

The situation in dual fungi culture was estimated on a 0-8 point scale 


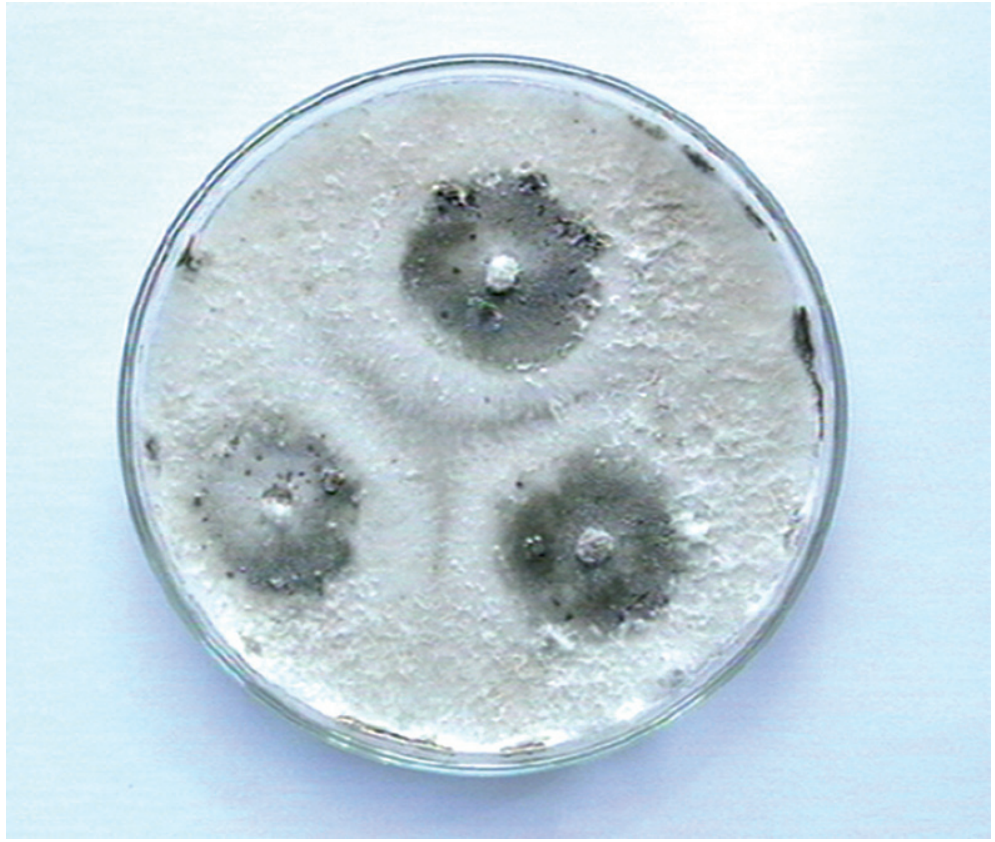

Fig. 1. 20-day-old colonies of $P$. diachenii K 255 with pycnidia on PDA. Photo: E. Zalewska.

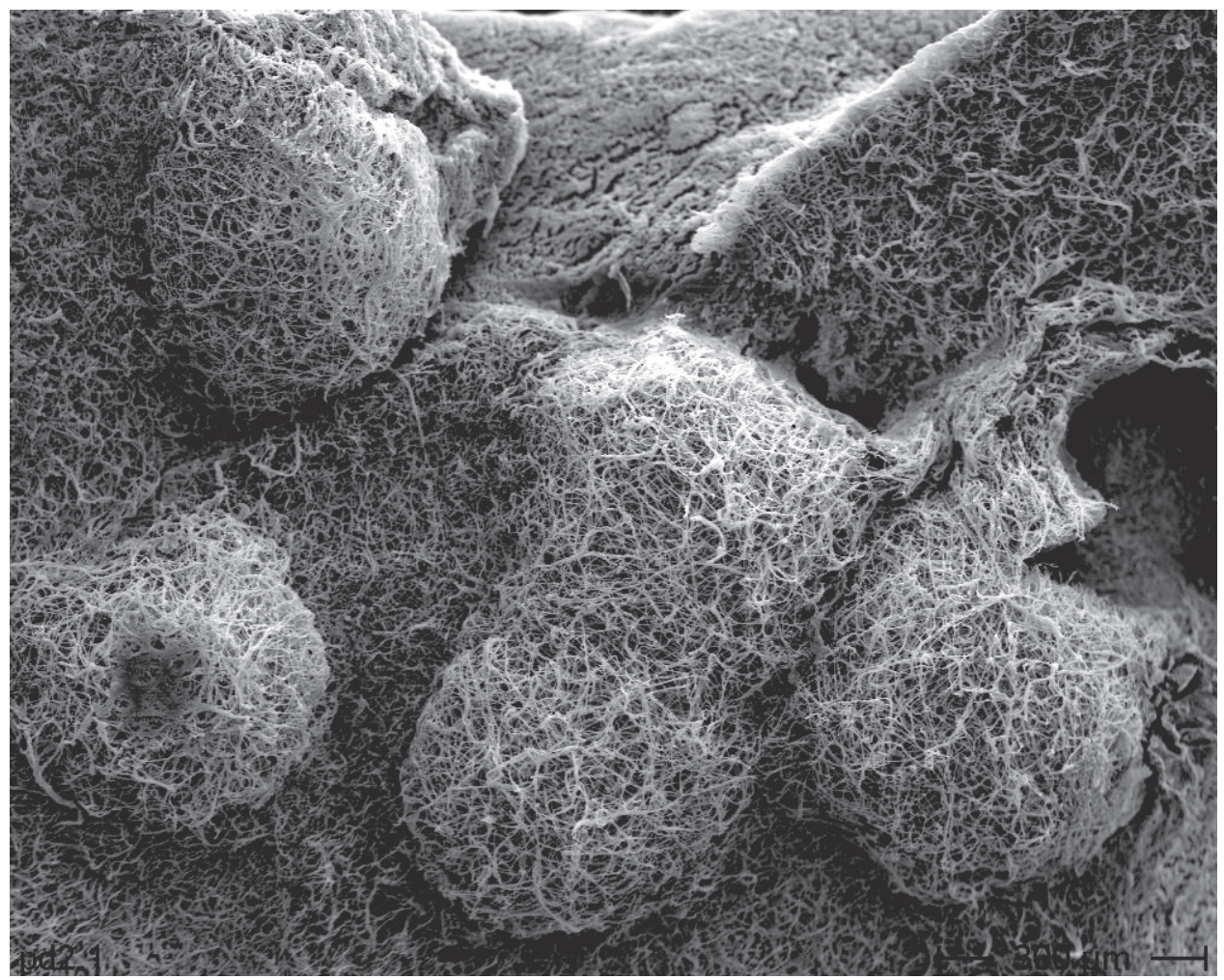

Fig. 2. Pycnidia of $P$. diachenii from PDA, SEM. Photo: M. Wróbel. 


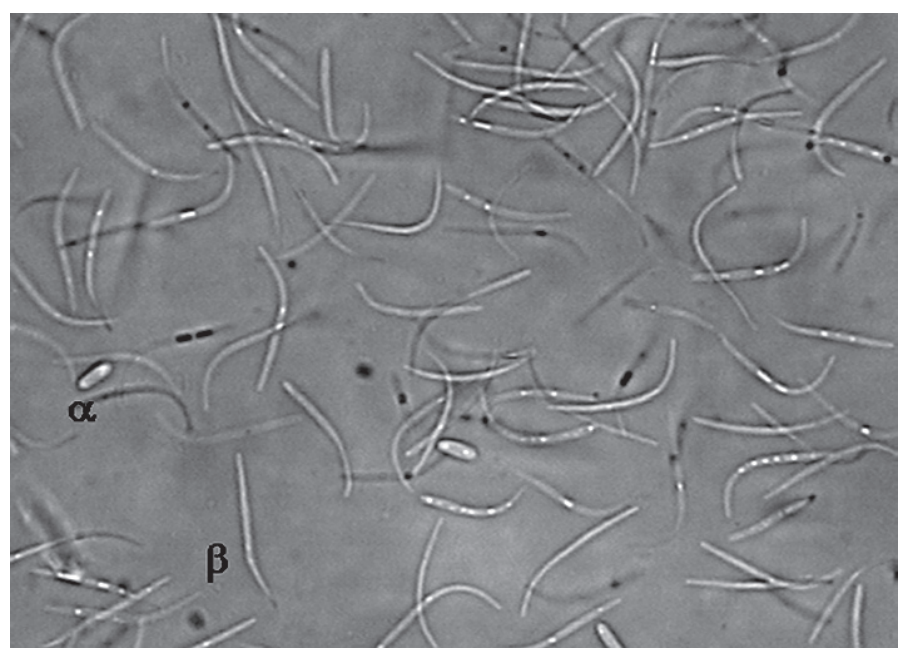

Fig. 3. Conidia $(\alpha, \beta)$ of P. diachenii on PDA. Photo: E. Zalewska.

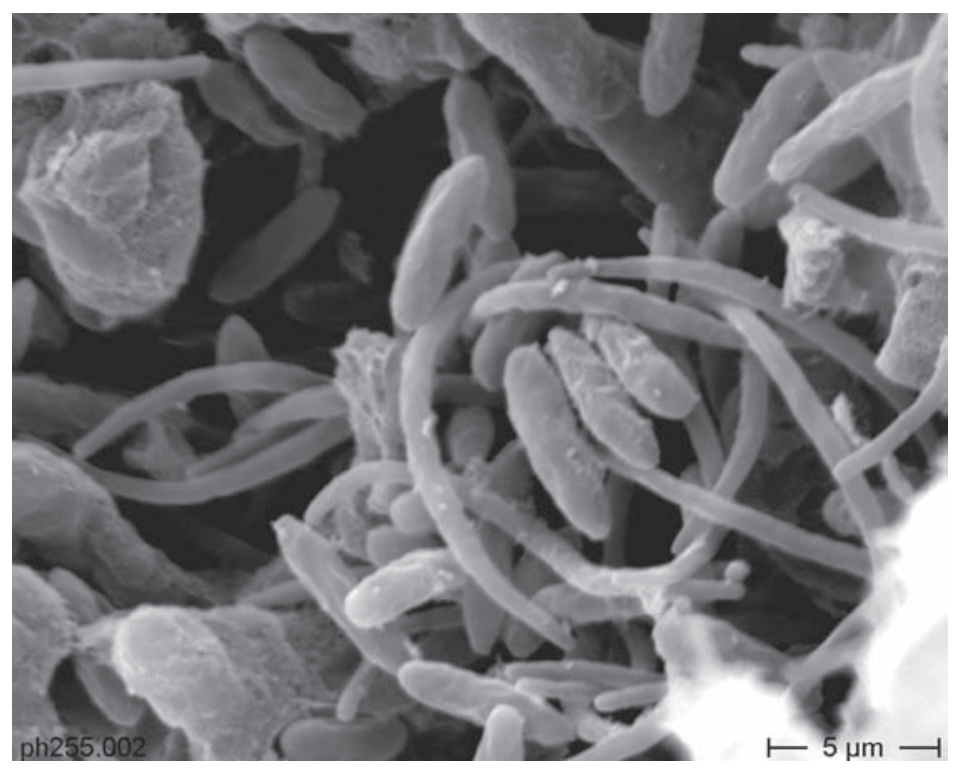

Fig. 4. Conidia $(\alpha, \beta)$ of P. diachenii, SEM. Photo: M. Wróbel. 


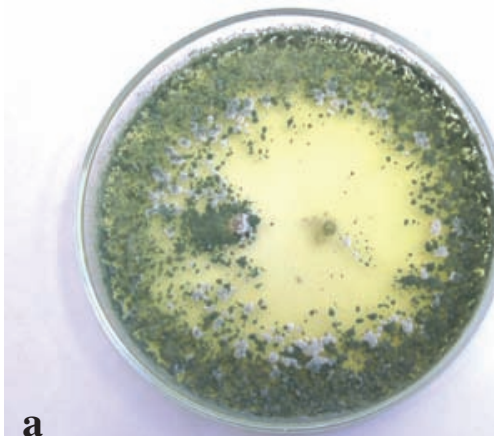

a

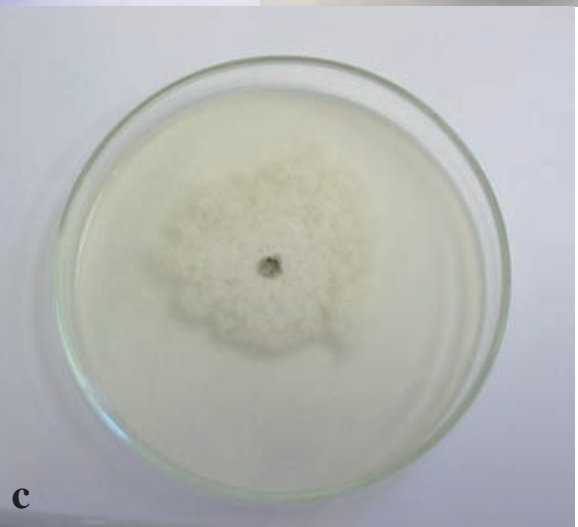

Fig. 5. Dual growth of $P$. diachenii (left) and Trichoderma koningii (right) after ten days - a, individual growth of T. koningii - b and P. diachenii - c. Photo: E. Zalewska.

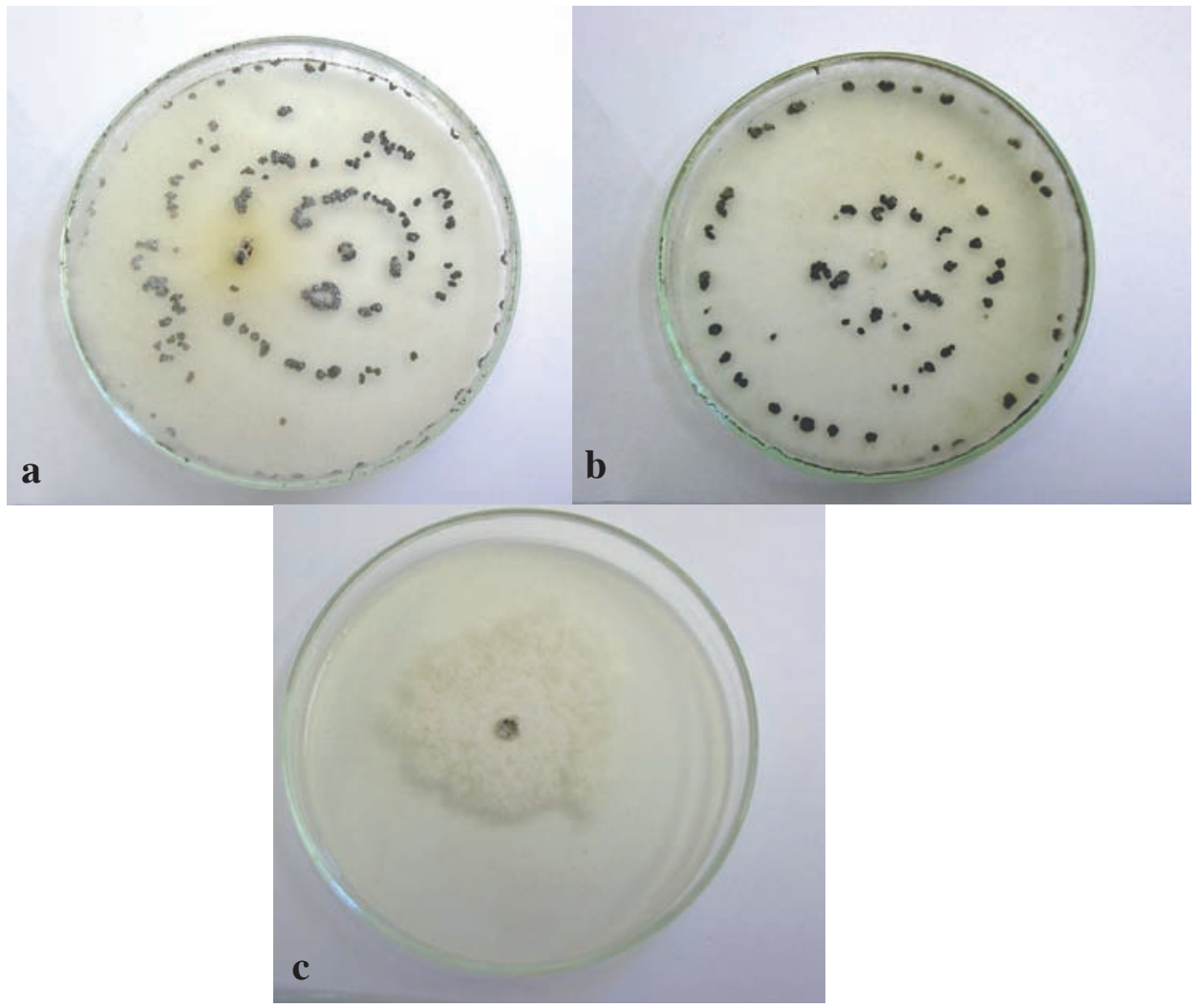

Fig. 6. Dual growth of $P$. diachenii (left) and Botrytis cinerea (right) after ten days - a, individual growth of $B$. cinerea $-\mathrm{b}$ and P. diachenii - c. Photo: E. Zalewska. 


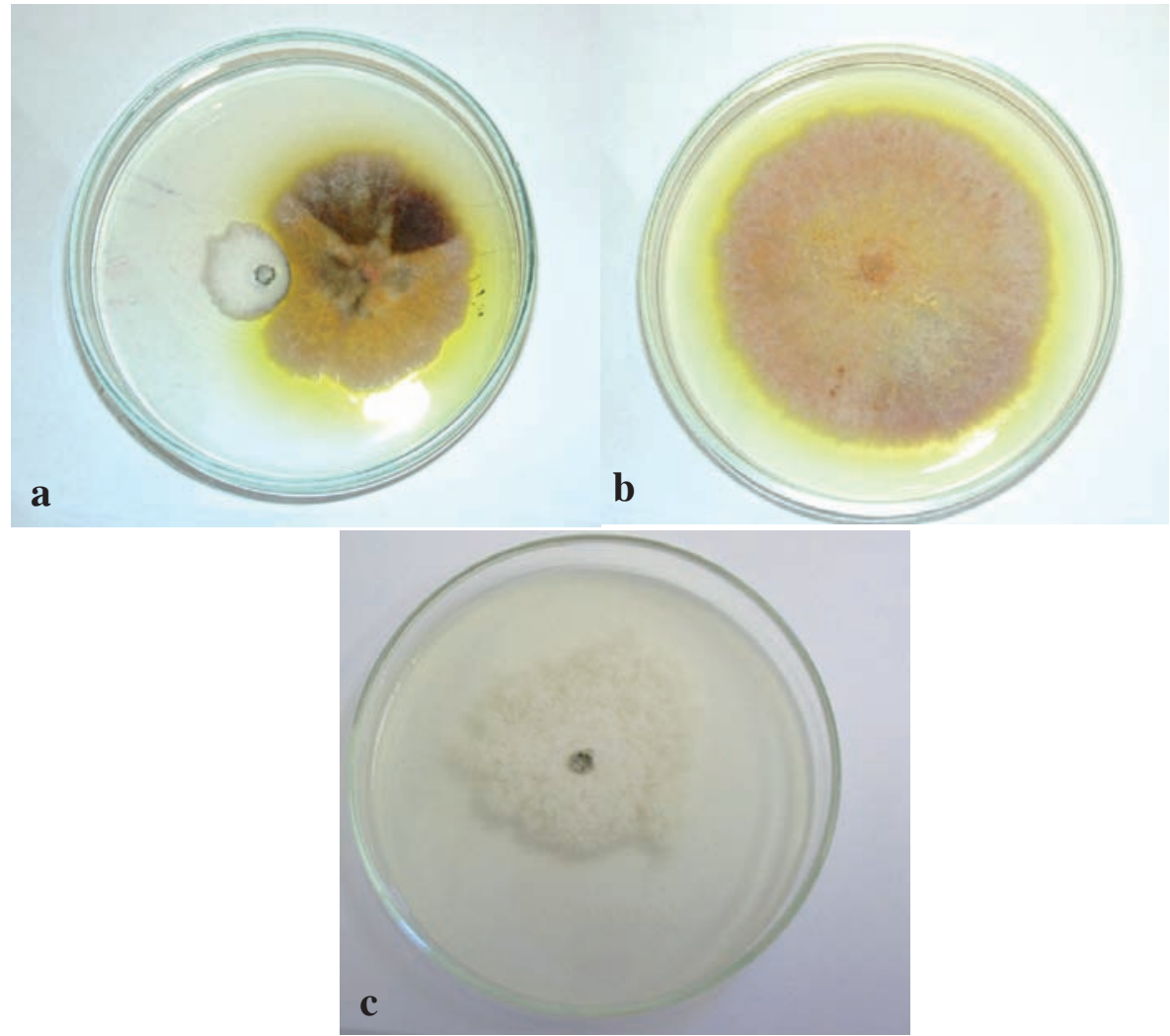

Fig. 7. Dual growth of P. diachenii (left) and Epicoccum purpurascens (right) after ten days - a, individual growth of E. purpurascens $-\mathrm{b}$ and P. diachenii - c. Photo: E. Zalewska.

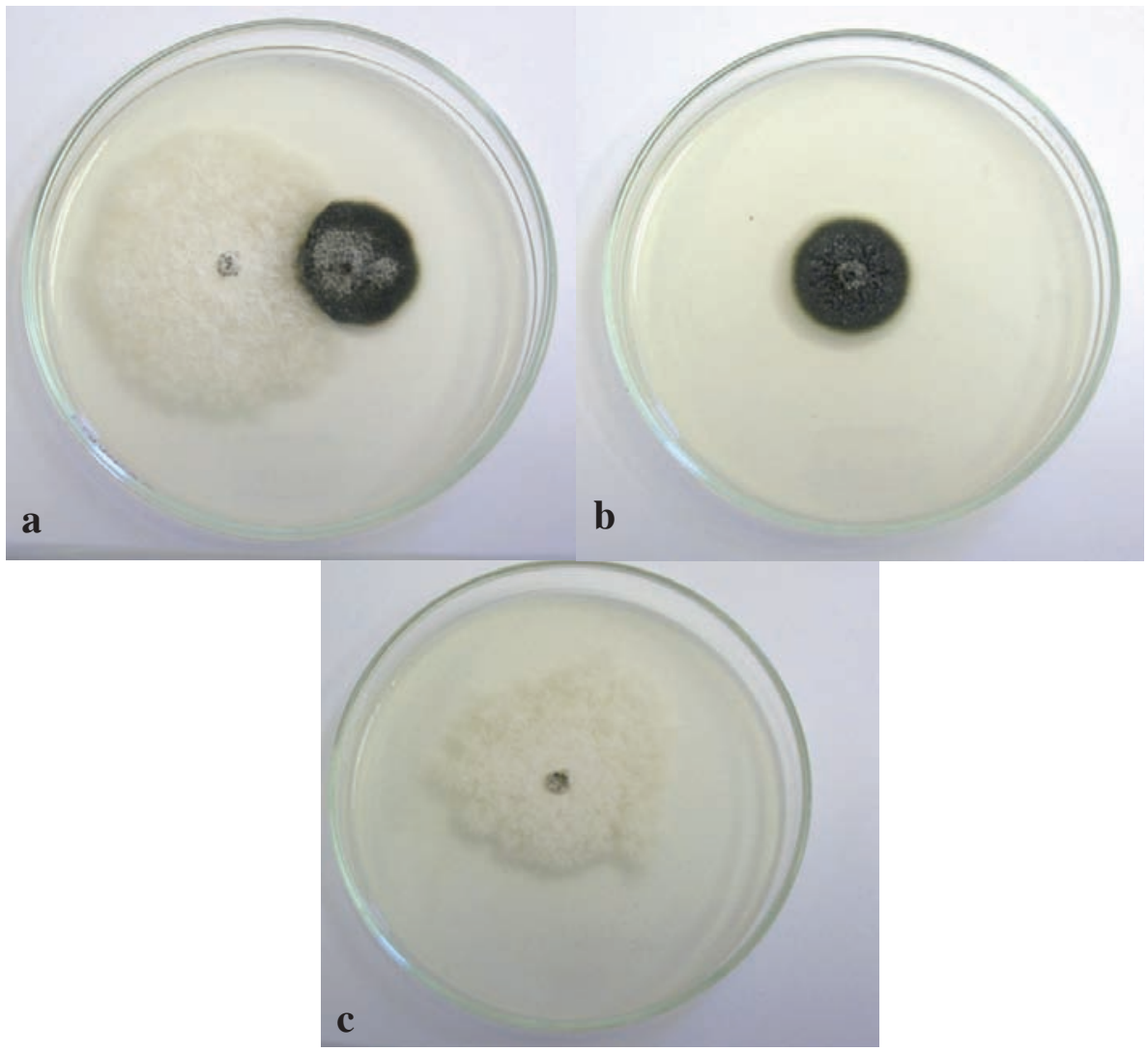

Fig. 8. Dual growth of P. diachenii (left) and Septoria carvi K 1833 (right) after ten days - a, individual growth of $S$. carvi - b and P. diachenii - c. Photo: E. Zalewska. 
days of cultivation from 85.0 to $90.0 \mathrm{~mm}$. The structures, especially fourteen- or twenty-day-old colonies, were rather compact, frequently zoned, with whitegray colour (Fig. 1). The reverse of the colonies was brown-gray to brown-black. Pycnidia of the fungus were formed after 10 or 14 days of culturing. The pycnidia were produced singly or in aggregates and they were immersed in the mycelium (Fig. 2). The size of pycnidia was differentiated and ranged from 300 to 864 $\mu \mathrm{m}$ (Tab. 1). Their walls were formed of a few thin layers of intergrown hyphae, which was visible under an electronic microscope (Fig. 2). In the studied isolates, the presence of conidia was noticed after 14 days of culturing at a temperature of $25^{\circ} \mathrm{C}$. The fungus formed oval $\alpha$ conidia, with one end slightly reduced and their size ranging from 9.25 to $20.35 \mu \mathrm{m}$ in length and from 2.5 to $4.6 \mu \mathrm{m}$ in width (Tab. 1, Figs 3, 4). In two conidia extremes, 2-3 guttulate conidia were observed. Conidia $\beta$ occurred in greater numbers in the older, i.e. 18-20-day-old colonies. They were straight or filiform to hamate and their size ranged from 24.83 to $32.47-\mu \mathrm{m}$ in length and $1.5 \mu \mathrm{m}$ in width (Tab. 1). The mature conidia emerged from pycnidia as big, thick and dull drops covering the ostiole of pycnidia. The macroscopic and microscopic features of the studied native isolates were similar to the features of the colonies of the foreign isolates.

Among the 20 tested fungi species, the majority, i.e. 15 , limited the growth of the pathogen after 10 days of dual growth, and in the case of 18 species of fungi after 20 days of dual growth (Tab. 2).

The fungi species from the genus Trichode$r m a$, i.e. T. harzianum, T. viride and T. koningii, totally limited the growth of both the studied isolates of $P$. diachenii after 10 and 20 days of dual growth with their IBE +8 (Tab. 2, Fig. 5). The fungi from the genus Gliocladium, i.e. G. catenulatum and G. roseum, slightly limited the growth of $P$. diachenii after 10 days of dual growth because IBE was +2 (Tab. 2). Just after 20 days of dual growth, G. catenulatum grew over the colony surface of the studied isolates and its IBE increased to +8 (Tab. 2). It was recognized that Trichoderma spp. and Gliocladium spp. caused total lysis of $P$. diachenii hyphae and pycnidia at the primary phase of their formation, and they made the production of conidia impossible.

Alternaria alternata, A. radicina and Cladosporium cladosporioides showed a neutral effect on $P$. diachenii after 10 days of dual growth with their IBE 0 (Tab. 2). Moreover, the above-mentioned fungi, after 20 days of dual growth, started to limit the growth of $P$. diachenii and their IBE was +5 and +3 for isolate 72 and +4 and +3 for isolate K 561 , respectively (Tab. 2).

The highest inhibitory effect on $P$. diachenii was caused by Botrytis cinerea, because both after 10 and
20 days of dual growth its IBE was +8 (Tab. 2, Fig. 6). Rhizoctonia solani limited the growth of two studied isolates after 10 days of dual growth and its IBE was +6 , and +8 after 20 days. On the other hand, on the surface of the $P$. diachenii inocula in dual culture with these fungi (B. cinerea and $R$. solani), single pycnidia and alive well-formed conidia $\alpha$ and $\beta$ were formed. The growth of $P$. diachenii was limited by Colletotrichum gloeosporioides too, as its IBE was +2 , and after 20 days of dual growth its inhibitory effect increased three times, as its IBE was +6 (Tab. 2). Between the colonies of $C$. gloeosporioides and $P$. diachenii, a small inhibition zone was formed. Similarly, during the dual culture of Epicoccum purascens (Fig. 7) or Fusarium avenaceum and $P$. diachenii, the inhibition zones were observed. The IBE of these fungi was +3 and +2 after 10 days and +7 and +6 after 20 days of dual growth, respectively (Tab. 2). The other species of fungi from the genera Fusarium limited the growth of the colonies of the studied isolates of $P$. diachenii in the scale from +2 to +4 after 10 days and from +4 to +6 after 20 days of dual growth (Tab. 2).

Phoma exigua limited the growth of ten-dayold colonies of isolate 72 of $P$. diachenii to the least extent, as the value of IBE for the fungus was +1 , but for isolate $\mathrm{K} 561$ of $P$. diachenii the effect of this fungus was neutral. After 20 days of dual growth, the biotic effect of $P$. exigua on $P$. diachenii changed and the value of IBE was +6 and +4 , respectively for isolates 72 and K 561. During the dual culture of $P$. diachenii with fungi species partly limiting its growth, in the middle or in the margin of the pathogen colony numerous pycnidia with $\alpha$ and $\beta$ conidia were observed. This fact indicates the big expansive character of this fungus.

Among the 20 tested fungi species, Septoria carvi and Colletotrichum dematium did not limit the growth of the colony of the $P$. diachenii isolates. Their IBE was negative both after 10 days (- 2 and -6$)$ and after 20 days of dual growth (-4 and -7$)$. Under these growth conditions, the studied isolates of $P$. diachenii partly limited the growth of $S$. carvi and $C$. dematium (Tab. 2, Fig. 8). During the dual culture of $P$. diachenii and $S$. carvi, on the surface of the colonies of each of the species pycnidia and conidia were formed, but the number of $P$. diachenii pycnidia was larger.

\section{DISCUSSION}

The macroscopic and microscopic features of the colonies, the morphology of pycnidia and conidia obtained in the present study, in comparison with the papers by Sut to n (1980) and Gabler and Ehrig (2000), provided the basis to recognize the studied fungi species as Phomopsis diachenii. 
It is the first piece of information about the occurrence of this pathogen on caraway cultivated in Poland. The fact that $P$. diachenii isolates were obtained from caraway plants has increased the number of fungi species described as colonizing this plant in Poland.

The studies of the biotic effect of the fungi indicate that $P$. diachenii is a weak competitor because its growth was limited by numerous species of phyllosphere fungi. This species may be eliminated from its ecological niche by other fast-growing fungi species. The results obtained in the present study indicate the dominance of biotic activity of $P$. diachenii over that of $S$. carvi. It is possible that $P$. diachenii has a greater possibility to survive in the phyllosphere fungal community than slow-growing species, i.e. S. carvi (M a c h ow i c z - S t e f a n i a k et al. 2008). It seems that, when the two above-mentioned species colonize a plant, $P$. diachenii will dominate. It is difficult to explain clearly why in geographical regions where there are similar climatic conditions the main pathogens of caraway were not the same fungi species ( $\mathrm{Gabler}$ and M a chow ic z-S tef a niak, 2003). Actually, it seems that $P$. diachenii is not domesticated on caraway cultivated in Polish conditions. On the other hand, in the presence of this fungus on caraway, the quantitative occurrence of the pathogen should be taken into consideration. The presence of numerous species of antagonistic fungi to $P$. diachenii on caraway suggests that the isolation of the fungus from plant tissues on artificial media is possible at the initial stage of the disease, which was indicated earlier with respect to $S$. carvi (M a c how i c z - S t e f a n i a k et. al. 2008).

Among the studied fungi, only Trichoderma spp, Gliocladium spp. and Epicoccum purpurascens were recognized as positive antagonistic fungi to $P$. diachenii. The high antagonistic activity of Trichoderma spp. result from their high competitive abilities, antibiosis as well as the ability to parasite (F o k ke $\mathrm{ma}$, 1995). The antagonistic effect of Gliocladium spp. with respect to $P$. diachenii was slow, because the antagonistic activity of these fungi results (unlike that of Trichodema) only from antibiosis and the ability to parasite (Fokkema, 1995; M a c how i c zS te f a ni k et al. 2008). Besides, Epicoccum purpurascens had possibilities to produce siderophores and toxic metabolites (Frederick et al. 1981; M a lle a et al. 1991).

All the other fungi species studied, including toxigenic species such as Fusarium spp. and Alternata spp., could not be recognized as positive antagonistic fungi because they are dangerous pathogens of many various cultivated plant (M án ka, 1974; G a b le r and Ehrig, 2000; Kusterer et al. 2002; M achowicz-Stefaniak and Zalewska, 2000; 2004; 2008).

\section{Acknowledgments}

We would like to thank Jutta Gabler, Ph.D., from BA f. Züchtungsforschung an Kulturpflanzen Inst. f. Resistenzforschung und Pathogendiagnostik in Aschersleben for sending three isolates of Phomopsis diachenii for research purposes.

\section{REFERENCES}

Farr D. F., Bills G.F., Chamuris G. P., Rossman A. Y., 1995. Fungi on plants and plant products in the United States. St. Paul, Minnesota USA.

Fokkema N. J., 1995. Strategies for biocontrol of foliar fungal diseases. [In:] M. Mańka (ed.), Environmental Biotic Factors in Integrated Plant Disease Control. Proceedings of the $3^{\text {rd }}$ Conference of European Foundation for Plant Pathology, Poznań, Poland, September 5-9, 1994. Polish Phytopathology Society: 69-79, Poznań.

Frederick C. B., Szaniszlo P. J., Vickrey P. E., Bentley M. D., Shive W., 1981. Production and isolation of siderophores from the soil fungus Epicoccum purpurascens. Biochemistry, Apr. 28, 20 (9): 2432-2436.

Gabler J., Ehrig F., 2000. Phomopsis diachenii Sacc., ein aggressiver Krankheitserreger an Kümmel (Carum carvi L.) - Erstnachweis für Deutschland. / Phomopsis diachenii Sacc., an important pathogen on caraway (Carum carvi L.) - First detection for Germany. Z. Arzn. Gew. Pfl. 1: 36-39.

Gabler J., Machowicz-Stefaniak Z., 2004. Kranheitsauftreten an Kümmel in Deutschland und Polen./ Diseases on caraway in Germany and Poland. Fachtagung für Arznei- und Gewürzpflanzen. 7-9 September 2004, Jena, Programm Abstract und postertexte: 88 .

Kusterer A., Taubenrauch K., Gabler J., Kühne T., 2002. Krankheitsauftreten an Kümmel (Carum carvi L.), Fenchel (Foeniculum vulgare Mill.) und Dill (Anethum graveolens L.) am Standort Aschersleben. / Diseases on caraway (Carum carvi L.), fennel (Foeniculum vulgare Mill.) and dill (Anethum graveolens L.) at the location Ascherleben. Z. Arz. Gew. Pfl. 7 Jg.: 387-391.

La in e A. L., 2003. First report of Phomopsis subordinaria in natural population of Plantago lanceolata in south-west Finland. Plant Pathol. 52: 422.

Machowicz-Stefaniak Z., 1998. Antagonistic activity of epiphytic fungi from grape-vine against Botrytis cinerea Pers. Phytopathol. Pol. 16. 45-52.

Machowicz-Stefaniak Z., Zalewska E., 2000. Grzyby występujące na nadziemnych organach leszczyny. [In:] M. Lisiewska and M. Ławrynowicz (eds), Monitoring grzybów: 153-166, Sekcja Mikologiczna PTB Poznań-Łódź 2000 (in Polish).

Machowicz-Stefaniak Z., Zalewska E., 2004. Grzyby zagrażające uprawie wybranych gatunków ziół z rodziny Apiaceae w południowo-wschodniej Polsce. / Fungi threatening some herb species from the Apiaceae family cultivated in south-east Poland. Folia Univ. Agric. Stetin., Agricultura, 239 (95): 223-228. 
Machowicz-Stefaniak Z., Zalewska E., 2008. Biodiversity of fungi colonizing various organs of caraway. EJPAU Horticilturae 2008 v. 11, Issue 1, http://www. ejpau.media.pl/volume11/issue1/art-21.html.

Machowicz-Stefaniak Z., Gabler J., Zalewska E., 2003. Patogeny zagrażające uprawie roślin zielarskich./ Pathogens threaten herb plants cultivation. Folia Horticulturae, supl. 1: 565-567.

Machowicz-Stefaniak Z., Zalewska E., Król E., 2008. Biotic effect of caraway phyllosphere fungi on the pathogenic fungus Septoria carvi Syd. Herba Pol. 54, (3): 70-80

Mallea M., Pesando D., Bernard P., Khoulalene B., 1991. Comparision between antifungal and antibacterial activities of several strains of Epicoccum purpurascens from the Mediterranean area. Mycopathologia, 115, (2): 83-88.

Mugnai L., Anzidei M., 1994. Casi di necrosi corticale da Phomopsis foeniculi del finocchio da seme in Italia./ Stem necrosis of fennel caused by Phomopsis foeniculi. Petria, 4: 237-244.

M a ń k a K., 1974. Zbiorowiska grzybów jako kryterium oceny wpływu środowiska glebowego na choroby roślin./Fungal communities as a criterion for estimating the effect of the environment on plant diseases. Zesz. Probl. Post. Nauk Roln. 160: 9-23.

M a ń k a M., 1995. Non pathogenic soil fungi reflecting soil environment. [In:] M. Mańka (ed.), Environmental Biotic Factors In Integrated Plant Disease Control. Proceeding of $3^{\text {rd }}$ Conference of European Foundation for Plant Pathology: 27-36, Poznań, Poland, September 5-9, 1994. Polish Phytopathology Society, Poznań.

Mańk a K., Mań k a M., 1992. A new method for evaluating interaction between soil inhabiting fungi and plant pathogens. IOBC/WPRS Bull. 15, (1): 73-75.

Rodeva R., Gable r J., 2004. First report of Phomopsis diachenii in Bulgaria. Mycologia Balcanica, 1: 153-157.

Saccardo P. A., 1915. Notae mycologicae. Annals Mycol. 13: 115-138.

S u t t on B. C., 1980. The Coelomycetes. Fungi Imperfecti with Pycnidia, Acervuli and Stromata. Kew (CMI)

Uecker F. A., 1988. A Word list of Phomopsis names with notes on nomenclature, morphology and biology. Mycol. Mem. 13: 231

Z a lew s k a E., 2008. Occurrence and characterization of Septoria carvi Syd. (Coelomycetes, Sphaeropsidales). Herba Pol. 54, (1): 25-33.

Zimowska B., 2008. Fungi threatening the cultivation of sage (Salvia officinalis L.) in south-eastern Poland. Herba Pol. 54, (1): 15-24.

\section{Występowanie i biotyczna aktywność Phomopsis diachenii Sacc.}

\section{Streszczenie}

Phomopsis diachenii wyizolowano po raz pierwszy w Polsce z roślin kminku zwyczajnego, odmiany Konczewicki w 2006 roku, a następnie w 2007 r. Pojedyncze kultury otrzymano z korzeni i szyjki korzeniowej ośmiu 6-tygodniowych siewek oraz z łodyg dwu roślin w drugim roku uprawy z objawami nekrozy. Grzyb wyizolowano z odkażonych powierzchniowo części roślin na pożywce maltozowej z dodatkiem 0,01\% streptomycyny. Identyfikację do gatunku prowadzono na pożywce PDA. Przebadano również biotyczne oddziaływanie pomiędzy $P$. diachenii i Septoria carvi oraz innymi gatunkami grzybów fylosferowych z kminku zwyczajnego. Na pożywce PDA w szalkach Petriego zakładano hodowle dwuorganizmowe, tj. składające się z P. diachenii i jednego z grzybów reprezentujących badane zbiorowisko. Biotyczne oddziaływanie grzybów w kulturach dwuorganizmowych oceniono po 10 i 20 dniach wspólnego wzrostu i wyrażono jednostkowym efektem biotycznym IBE. Wykazano, że $P$. diachenii posiada niewielkie właściwości konkurencyjne. Jego wzrost ograniczają liczne gatunki szybko rosnących grzybów fylosferowych. Uzyskane wyniki wskazały na przewagę właściwości biotycznych $P$. diachenii nad Septoria carvi. Można wnioskować, że $P$. diachenii ma większe możliwości utrzymania się w zbiorowiskach grzybów fyllosferowych niż $S$. carvi, powodujący septoriozę kminku. 
